\title{
At the Junction: Two Models of Business Responsibility for Modern Slavery
}

\author{
Janne Mende ${ }^{1,2}$ (D) Julia Drubel ${ }^{2}$
}

Published online: 6 June 2020

(C) The Author(s) 2020

\begin{abstract}
This article develops a conceptual pattern of the reasons and scope of business responsibility for modern slavery. It introduces modern slavery as either relation or structure and designs an understanding of a broad and a narrow model of business responsibility, consisting of business power, internal and external realms of business conduct and public and private roles of companies. Crossing the two models of modern slavery with the two models of business responsibility, the article carves out the strengths and limits of their junctions. The continuous pendulum between the junctions allows to discuss how and why companies can be responsible for modern slavery. It thus contributes analytically, practically and normatively to tackling modern slavery.
\end{abstract}

Keywords Business power $\cdot$ Modern slavery $\cdot$ Business responsibility $\cdot$ Corporate governance $\cdot \mathrm{CSR} \cdot$ Human rights

Janne Mende

janne.mende@sowi.uni-giessen.de

Julia Drubel

julia.drubel@sowi.uni-giessen.de

1 Institute for Political Science, Technical University Darmstadt, Dolivostr. 15, 64293 Darmstadt, Germany

2 Department of International Relations, Justus-Liebig-University Giessen, Karl-Gloeckner-Str. 21, 35394 Giessen, Germany 


\section{Introduction}

Modern slavery ${ }^{1}$ is one of the human rights violations that are unanimously condemned worldwide. "The fight against slavery is one of the very few human rights imperatives that attracts no principled dissent. Indeed, the duty to eradicate slavery is one of only [a few] human rights clearly identified by the International Court of Justice as an erga omnes norm" (Hathaway 2008, 7-8). At the same time, legislation and implementation is highly irregular (Schwarz and Allain 2020), and slavery or slavery-like conditions persist (Landman 2018). In times of global markets, supply chains, production networks and globally intertwined economies, with companies gaining power, resources and agency, states as well as civil society actors increasingly are addressing business enterprises for tackling modern slavery. This interlocks with a growing body of research exploring business responsibilities and corporate governance with regard to modern slavery (Fransen and Lebaron 2018; Gold et al. 2015; Gold and Schleper 2017).

These developments fuel the more general discussion as to how and why business companies can assume responsibility for modern slavery. This question is demanding because it rests on two highly ambiguous terms. Modern slavery, on the one hand, and business responsibility, on the other, represent two distinct fields of controversy and polyvalence that can hardly be boiled down to handy definitions, let alone when brought together.

Against this backdrop, this article develops a pattern that entails the complexity of both. It proposes two models of business responsibility for two models of modern slavery, in order to discuss how and why companies can (not) tackle modern slavery. The article thus contributes normatively, practically as well as analytically to approaches to tackling modern slavery. Normatively, the article aims at a human rightsbased abolishment of modern slavery. Practically, the article addresses the strengths and limits of corporate governance and CSR policies against modern slavery. Analytically, the article discusses the strengths and limits of broad approaches and connects them with more concrete business strategies. This connection, as we will argue, is based upon the mutually constitutive relationship between modern slavery as structure and modern slavery as relation. Ultimately, we propose a conceptual pattern consisting of (a) a broad business responsibility for slavery as structure and (b) a narrow business responsibility for slavery as relation. We suggest that only a continuous pendulum between the two can properly address business responsibilities for modern slavery.

Our focus on modern slavery needs a refinement. It cannot tackle all forms of modern slavery, but only those forms that are business-related. Numerous forms of modern slavery do fall into this range, such as debt bondage, chattel slavery, contract slavery, forced or compulsory labour, most cases of trafficking (Mende 2019), and more generally, slavery-like working conditions in almost every industry, especially in

\footnotetext{
${ }^{1}$ Some studies reject the term modern slavery due to the blurry demarcation between modern and historical forms of slavery (Quirk 2012). Others prefer the term contemporary slavery (Brysk 2012). Other studies criticise that both terms negate the blurry lines between free and unfree forms of exploitation and indecent work (O'Connell Davidson 2015). We use the terms modern slavery or slavery to refer to slavery that contemporarily exists in multiple forms, and that may or may not resemble historical forms of slavery and other forms of indecent work, (Allain 2013). For a conceptual overview and a critical discussion of the term modern slavery, cf. Mende 2019.
} 
brick lanes, agriculture, construction sites, fishing, electronics and the apparel industry (Gold et al. 2015).

There are other forms of modern slavery that do not clearly fall into this range, such as domestic slavery in private households, restavecs (children given into domestic service), cult and ritual slavery or forced and servile marriage (Miers 2000, 2003; Akurang-Parry 2010; Greene 2009; Lawrance 2010). While those forms also may include economic exploitation, for the purpose of this paper, we draw a distinction between business-related and non-corporate exploitation, focussing on the former. Domestic slavery in private households does not affect business responsibility, whereas the commercial use of enslaved domestic workers by an employment agency or hired by a company does. Hence, the article addresses modern slavery in the economic sphere, ${ }^{2}$ focussing on the aspect of exploitation for commercial purposes.

"Forms of Modern Slavery" introduces two main approaches to modern slavery as relation or as structure. While both approaches are interconnected, their different foci display differing effects and implications that allow for an analytical distinction between the two. Most importantly, they differ in terms of causal logics and problem definition. "Forms of Business Responsibility" designs an understanding of business responsibility based on business power, the internal and external realms of business agency and business as a public or private actor. It develops two models of narrow and broad business responsibility. "The Junction: Business Responsibility for Modern Slavery" discusses the junctions between the models, crossing a narrow model of business responsibility with modern slavery as relation, and a broad model of business responsibility with modern slavery as structure. "Strengths and Limits" demonstrates the necessity of a continuous pendulum between the two junctions. Overall, this article develops a pattern that contributes to the question of how and why business companies can assume responsibility for modern slavery.

\section{Forms of Modern Slavery}

Concepts of modern slavery differ in terms of causal logics and the identification of challenges and problems. This leads to different solutions, strategies and delineations of responsibilities (Young 2006). International documents as well as scholarly approaches cover a broad range of modern forms of slavery. These legal and scholarly approaches build an essential basis for modelling the concept of modern slavery. This section provides an insight into current definitions and concepts, showing that they can be divided into two main approaches. Modern slavery is perceived as relation, on the one hand, and as structure, on the other. Note that this is an analytical, not a dichotomous distinction. It is based on a mutually constitutive relation between agency and structure. Agency and structure are mediated in that each constitutes and reproduces the other. At the same time, they remain analytically and logically distinct (Mende 2016, 49-62). In this mutually constitutive relation, slavery as structure supervenes slavery as relation. This means that change in the structure will initiate change in the relation, while this is not necessarily the case the other

\footnotetext{
${ }^{2}$ Note that our discussion of the hybrid role of business between public and private below indicates an understanding of the economic sphere that is not dichotomously separated from the political nor from the private sphere (Cutler et al. 1999, 272).
} 
way round. The mediated understanding is able to prevent an interpretation that dichotomously detaches structure from agency - and modern slavery as relation from slavery as structure. However, by analytically distinguishing between the two, this section provides a pathway to the manifold approaches to modern slavery.

The term slavery is often used to denote historical forms of labour exploitation, e.g. the recruitment of indigenous people for labour in the colonies or the transatlantic slave trade (Dottridge 2005). In this historic context, the League of Nations prominently delineates slavery in its Slavery Convention from 1926. It defines slavery as "the status or condition of a person over whom any or all of the powers attaching to the right of ownership are exercised" (League of Nations 1926, Art 1.1). The Convention further includes a provision to prevent compulsory or forced labour (Art. 5), thereby addressing the widespread use of forced labour in colonised countries, even after the formal abolition of slavery (Ollus 2015, 103).

The Vienna Convention on the Law of Treaties states that, in addition to the sociohistorical context within which international treaties are developed, "any subsequent agreement between the parties regarding the interpretation of the treaty or the application of its provision" (United Nations 1969, Art 31.3a) are to be taken into account. Thus, for the contemporary context, the Convention has to be examined in line with younger documents and with the United Nations human rights system. This includes the following reports and legal documents:

-1951 the report of the Ad-Hoc Committee of Experts on Slavery to the ECOSOC (Ad Hoc Committee on Slavery 1951),

-1953 the report by the Secretary General (United Nations Secretary General 1953),

- 1956 the Supplementary Convention on the Abolition of Slavery, the Slave Trade, and Institutions and Practices Similar to Slavery (Supplementary Convention) (United Nations 1956),

-2000 the first Additional Protocol to Prevent, Suppress and Punish Trafficking in Persons, Especially Women and Children (Palermo Protocol) (United Nations 2000).

These reports and instruments confirm the "Slavery Convention as the authoritative source on what counts as slavery in law" and its applicability to modern slavery (Allain and Hickey 2012, 916). Moreover, they build the basis for national legislation regarding modern slavery, e.g. the United States Victims of Trafficking and Violence Protection Act (2000), the UK Modern Slavery Act (2015) and the Australia Modern Slavery Act (2018), elements of which are used as a guidance for global politics again. Adapted from this corpus of legal documents, together with scholarship from political science, economics and the social sciences, we differentiate modern slavery as interpersonal relation and modern slavery as structure as follows.

\section{Modern Slavery as Relation}

Concepts of modern slavery as an interpersonal relation mainly draw upon the legal notions in international law. This is because a legal perspective usually needs concrete action by a concrete agent that is linked to a certain incidence of modern slavery, both demanding for clear definitions. ${ }^{3}$ In this context, slavery means the servile status of a

\footnotetext{
${ }^{3}$ Cf. the "liability model" of responsibility in Young 2006.
} 
person in relation to another person, characterised by "any or all of the powers attaching to the right of ownership" (United Nations 1956, Art. 7a). These powers are defined as absolute, executed over the person of servile status, serving the extraction of labour power, and they can be transferred (Allain 2013, 28). The most basic feature of ownership is possession, manifesting in claim-rights, liberties, powers and immunities (Allain and Hickey 2012, 925-30).

Since slavery is legally banned worldwide, ownership rights have been abolished. Nonetheless, slaveholders can still enforce de facto ownership without the de jure rights of ownership in a person. Slaveholders use de facto liberties, powers and immunities in order to exercise control over a person. They do so intentionally. ${ }^{4}$ The modern reality of slavery translates into controlling a person "in such a way as to significantly deprive that person of his or her individual liberty, with the intent of exploitation through the use, management, purchase, sale, profit, transfer or disposal of that person" (Allain 2013; Research Network on the Legal Parameters of Slavery 2012, 2).

Thus, the first defining feature of modern slavery as relation is a de facto right to ownership as the execution of control of a person over another person. The relation is, second, of an involuntary nature, because third, it is marked by violence or its threat. The usage of coercion refers only to direct legal, political or other interpersonal means (ILO 2012). A situation in which a person is "forced into dangerous or difficult work by economic circumstances or other impersonal forces" (Craig et al. 2007, 13) is not covered by the approaches to slavery as relation (Galtung 1969). Fourth, this relation exists with the intention of exploitation. While structures and institutions can be exploitative as well, the intention of exploitation marks slavery as relation.

Very similar meanings can be found in international approaches to forced labour (Drubel 2019), and to trafficking, respectively. The ILO delineates forced or compulsory labour as "all work or service which is extracted from any person under the menace of any penalty and for which the said person has not offered himself voluntarily" (ILO 1930, Art. 2.1). ${ }^{5}$ Physical or psychological coercion, e.g. physical violence, threats, deception, the involuntary entrance into the labour relation or the impossibility to leave the relationship, constitute coercive means:

While sometimes the means of coercion used by the exploiter(s) can be overt and observable (e.g., armed guards who prevent workers from leaving, or workers who are confined to locked premises), more often the coercion applied is more subtle and not immediately observable (e.g., confiscation of identity papers, or threats of denunciation to the authorities) (ILO 2012, 19). ${ }^{6}$

Similar connections apply to the term trafficking (United Nations 2000, Art. 3a). At the beginning of the twentieth century, the term trafficking has been used to describe how women

\footnotetext{
${ }^{4}$ Those intentions may be grounded in slaveholders' rationalization strategies of patronization (ChoiFitzpatrick 2017), in management strategies such as insulation (Crane 2013), and in social conditions such as links and networks among exploitative employers (Chesney et al. 2019).

${ }^{5}$ It excludes military service, normal civic obligations or labour assignments in contexts of legitimate imprisonment as well as labour extracted in the event of an emergency (ILO 1930, Art. 2.2).

${ }^{6}$ Forms of deception as lying, brainwashing or indoctrination also constitute direct forms of psychological violence, because they decrease a person's means to realise her potential (Galtung 1969, 169).
} 
are moved from one country to another for the purpose of sex work or sexual exploitation. In 2000, the United Nations (UN) redefined the term as a practice of recruitment into modern slavery or forced labour including commercial sexual exploitation (Dottridge 2005, 707), or the "movement of people for the purpose of their exploitation" (Lerche 2007, 427).

While there are differences between modern slavery, forced labour and trafficking, they all amount to the four characteristics of slavery as relation: the de facto ownership of another person, the involuntary nature of the relation, the interpersonal use or the threat of violence and the intent of exploitation (Bales 2005, 4; Choi-Fitzpatrick 2012, 16; Craig et al. 2007, 12; Herzfeld 2002, 50; Moravcsik 1998, 174).

\section{Modern Slavery as Structure}

While interpersonal relations are a necessary condition for modern slavery, they may not be sufficient to understand and hence tackle modern slavery. Therefore, a body of scholarship focusses on the structures and institutions that constitute and enable slavery (Dottridge 2005; Miers 2000, 715). These approaches understand modern slavery as structure. They address first, impersonal forces and their embedding, second, its cross-level and cross-dimensional character to which actors can, third, contribute unintentionally.

First, the central criterion defining modern slavery as structure is impersonal force. This means that control is not only exercised via direct, interpersonal means of coercion or the threat thereof, but also by creating or using political, social, cultural, religious and economic contexts that make people more likely to be affected by modern slavery.

In this regard, the United States Victims of Trafficking and Violence Protection Act of 2000 diverges from the international approaches to slavery as relation, because it explicitly addresses structural violence and inequalities as causes for modern slavery. It states that "traffickers primarily target women and girls, who are disproportionately affected by poverty, the lack of access to education, chronic unemployment, discrimination, and the lack of economic opportunities in countries of origin" (United States of America 2000, Section 102.b.4). Similarly, social human rights perspectives are able to include and acknowledge structural inequalities (Mende 2019). This is because modern slavery is embedded in geographic, societal, political and historic structures (N. Taylor 2014, 133-34; Mezzadra and Neilson 2013, 105), ${ }^{7}$ dependent on economic and sociopolitical context as well as their global ties (N. Taylor 2014, 133-34; Lebaron and Ayers 2013, 875; Peterson 2003, 45; Storper and Walker 1989, 154). Poverty and rural deprivation can make people more vulnerable to modern slavery. Likewise, political structures can tremendously enable modern slavery, such as repressive migration regimes which feed into informal labour, or anti-migration politics which even may expose victims of modern slavery to detainment, harassment and deportation (Brysk $2012,73-85)^{8}$

The enslavement of people from certain population groups is exacerbated in societies that are stratified along racist, sexist or other axes of structural inequality that are

\footnotetext{
${ }^{7}$ Accordingly, labour as commodity and the status of this commodity among others is not fixed (Mezzadra and Neilson 2013, 100,102) and cannot be reduced to contracted wage labour (van der Linden 2008; Storper and Walker 1989, 151).

${ }^{8}$ Regarding the role of the state in providing the political conditions under which forced labour can thrive, see (Lebaron and Phillips 2018). Sylwester 2014 furthermore shows how cross-dimensional effects with regard to migratory and environmental policies feed into issues of trafficking and forced labour exploitation.
} 
Table 1 Two models of modern slavery

\begin{tabular}{|c|c|c|}
\hline \multicolumn{2}{|l|}{ Modern slavery as relation } & $\begin{array}{l}\text { Modern slavery as structure } \\
\text { 1. Impersonal forces }\end{array}$ \\
\hline $\begin{array}{l}\text { 1. De facto ownership } \\
\text { 2. Involuntary } \\
\text { 3. Use or threat of violence } \\
\text { 4. Intent of exploitation }\end{array}$ & $\begin{array}{l}\underset{\text { mutual constitution of }}{\leftrightarrow} \\
\text { agency and structure } \\
\text { structures supervene } \\
\stackrel{\leftarrow}{\text { relations }}\end{array}$ & $\begin{array}{l}\text { 1. Impersonal forces } \\
\text { 2. Cross-level and cross-dimensional effects } \\
\text { 3. Unintentional }\end{array}$ \\
\hline
\end{tabular}

justified by caste, tradition, religion or post-colonial legacies. "Slave-traders use local beliefs and traditions to gain control over individuals [...] where differences of race, ethnicity and religion still form the dividing lines between being slave and free" (Gold et al. 2015, 487, also cf. Crane 2013, 57; Bales 2016).

Second, the structures of inequality and impersonal forces interact between different dimensions and different spatial levels. They can exacerbate or contradict each other, with differing effects on modern slavery. The structures unfold cross-dimensional effects, e.g. when economic exploitation is enabled by cultural or religious vulnerabilities, by racism or sexism, ${ }^{9}$ and they interact between global, regional, domestic and local levels, e.g. belief systems, economic rules and inequalities or environmental politics (Sylwester 2014, 45358). Of particular importance is the dimension of political economy on the global level (Harvey 2006; Massey 1995; Scholte 2005; M. Taylor 2008a). It comprises varying rules concerning finance, trade, business and migration. It is constituted via business practices like foreign direct investments intending to organise production processes in global supply chains (Mosley 2011) ${ }^{10}$ and by national policies that aim at, e.g. the creation of offshore centres or Export Processing Zones. ${ }^{11}$ These operations and policies, their "heterogeneous constitution of global space" (Mezzadra and Neilson 2013, 97), can both strengthen and weaken impersonal forces and local structures of inequality. They can thus promote and prevent modern slavery.

Hence, third, these structures capture slavery not as a singular entity, but as a social process that is marked by vulnerabilities, constraints and options that an individual or a group of individuals is facing within certain constellations. For this reason, actors can contribute to modern slavery indirectly and unintentionally.

Ultimately, while definitions of slavery as relation are able to detect incidences of slavery of various kinds, structural definitions uncover constitutive elements and modalities enabling modern slavery.

\section{Modern Slavery: a Pathway}

This section discusses modern slavery as relation on the one hand and as structure on the other hand (cf. Table 1). While both terms can be analytically distinguished by means of their definitions, implications and effects, they are not dichotomous, but entangled. They are intermediated and mutually constitutive, because slavery as

\footnotetext{
${ }^{9}$ See for example McGrath 2012 about the racialization of migrant workers in the sugar cane production in Brazil.

${ }^{10}$ Crane et al. 2017 theorise the embeddedness of forced labour within business models of global and local production.

${ }^{11}$ See Lusk and Lucas 2009, 51-52 on the supply and demand side of cheap or even costless labour.
} 
structure contains relational constellations. This can be understood in a broad way: social structures consist of and are constituted by social relations. Determinants of structure such as poverty or racism are neither natural nor simply given, but products of society. Vice versa, slavery as relation is enabled (or disabled) by the structures within which it is embedded. Structural factors such as social stratification, the supply of work forces (Barrientos et al. 2013) or the density of exploitative employers (Chesney et al. 2019) strongly impact the likelihood and persistence of relations of slavery. Slavery as structure even supervenes upon slavery as relation, as it may affect the latter stronger than the other way around.

Modern slavery as structure and modern slavery as relation also share central features. Both acknowledge the involuntary nature of slavery and the exercise of control over the affected person. At the same time, their analytical distinction allows descriptions and explanations that are peculiar to each. Approaches to modern slavery as structure argue that neither the involuntary conduct nor the forms of control exclusively manifest in direct legal, political, physical or psychological coercion. They consider patterns of vulnerabilities, restrictions, and options that enable and promote the enslavement of individuals or certain groups of individuals. Therefore, we do not argue that structures cause slavery, but that structures provide the conditions under which modern slavery manifests.

Modern slavery as relation identifies and describes direct and intentional actions. The identification of a concrete case of modern slavery as relation is an important prerequisite for tackling it. Additionally, by providing and defining distinctive features, approaches to modern slavery as relation are able to distinguish slavery from nonslavery - a distinction that approaches to modern slavery as structure may be struggling with (e.g. O’Connell Davidson 2015).

In conclusion, the relational approach is a starting point to identify cases of modern slavery, while the structural approach allows taking into account less obvious forms of violence, and determining sources, reasons and explanations for modern slavery. The analytical differentiation allows considering modalities of modern slavery and determining which types of modern slavery affect business responsibility.

\section{Forms of Business Responsibility}

A discussion of business responsibility for modern slavery does not only depend on legal, conceptual and political definitions of modern slavery. It also needs to qualify the forms and scope of a company's responsibility for targeting and abolishing modern slavery. Current discussions about business responsibilities can be roughly divided into two strands. The first strand descends from the concept of corporate social responsibility (CSR). Its core meaning focusses on voluntary principles and commitments of companies to contribute to certain public interests and social values, i.e. to engage with issue areas beyond (or equivalent to) the immediate interests of the company (de Bakker et al. 2005; Lockett et al. 2006; Carroll 2008; Crane et al. 2008a, b; Gond and Moon 2012; Haynes et al. 2013; Kelling et al. 2020). This broad notion is shared by the otherwise highly pluralist approaches to CSR, which differ with regard to the scope and forms of CSR as well as its rationale. CSR approaches range from narrow economic (Friedman 2007) to broad public and political (Rasche 2015; Scherer and 
Palazzo 2011) perspectives. They are guided by business interests (Kurucz et al. 2008) or ethics (Campbell 2012). This range will be mirrored in our two models below.

The second strand of discussions about business responsibilities is dedicated to the area of business and human rights (BHR) (Addo 1999; Cragg 2012; Deva 2013; Ramasastry 2015). While it shares with CSR the notion of business commitment to social issues, it diverges from CSR in being narrower and broader at the same time. It is narrower in focussing on human rights as one issue area of social commitment. It is broader in including the possibilities of binding rules and law, both on the national and the global level, rather than solely relying on voluntary commitment, incentives or overlaps between social and business interests. It thus also includes more actors, levels of governance and forms of responsibilities than CSR with its focus on corporate governance.

In spite of their differences, the two strands CSR and BHR overlap in three important regards. This article draws on these overlaps, rather than on the differences. For both, the power of companies (or the lack thereof) plays a crucial role for addressing companies as responsible actors in the first place. Second, CSR and BHR both spring from the notion that business behaviour can have not only internal, but also external effects. However, the two strands differ with regard to the evaluation of the extent of the effects and the power of companies. Third, for both strands, the differentiation between public and private roles of companies is pivotal. In the international human rights regime, the classic notion of public actors as human rights actors is challenged in light of the power of companies as non-state, i.e. private actors. The CSR debates, on their part, are marked by the question, whether, and to what extent, companies as private actors should get involved with social values in the public sphere (Mende 2020a).

The following section operationalises business responsibility on the basis of these three, closely interrelated aspects from the overlapping strands of CSR and BHR, situating each of them in a spectrum between a narrow and a broad concept of business responsibility. Therefore, we employ a concept of business responsibility that goes beyond CSR and that is connected to a human rights-based approach.

\section{The Power of Business}

The first aspect of business responsibility captures the power of companies which directly speaks to the forms and scope of responsibility that a company can bear. Generally, there is a strong link between expectations placed upon a subject of responsibility, and the capability, i.e. the power of said subject to meet those expectations. The two are, however, not identical. The formulation of normative expectations can serve different purposes (e.g. the rise of public attention). Additionally, there is the danger of undercutting the desirability of normative expectations due to their feasibility. Still, there is a strong connection between power and responsibility. Normative expectations will not be able to generate substantial measures of responsibility, if they completely disregard the addressee's power to assume them. Furthermore, the power of companies fuels CSR and BHR demands in the first place. A discussion of business responsibility therefore has to take business power into account.

The concept of power is a matter of broad and heterogeneous discussion. Reconceptualizing the three dimensions of power according to Lukes, business power 
can be discussed as instrumental power, productive power and discursive power (Lukes 2005; Fuchs 2005, 90-96, 2004; Mende 2020b). Instrumental power captures the material base of power, closely tied to the size, resources, and wealth of a company (Epstein 1973, 1974), as well as direct, linear and causal relations of influencing policy output, the most prominent examples of which are lobbying and patronage. Productive power relates to the capabilities of companies to influence policy input, rule-setting, and which topics to exclude from decision-making processes in the first place. Discursive power, in turn, relates to affecting norms, ideas, social discourse, culture and communication, yet not by means of direct and causal influence, but by using soft mechanisms such as socialization, manipulation and persuasion (Fuchs 2004, 13638). ${ }^{12}$ Discursive and productive forms of power mainly depend on immaterial factors and a company's legitimacy and reputation, such as the moral standing, the quality of expertise, the financial relations or the local integration of a company.

We suggest aligning these three forms of business power with the scope of business power, and to situate them on a spectrum. At one end of the spectrum is an extensive model of power. Here, contemporary approaches equate business power of multinational corporations with a "quasi-governmental position" (Wettstein 2009, 213). This is due to their power to rule people, markets, governments, international organizations and themselves. According to this view, the power of transnational corporations could not possibly be overrated, since there seems to be almost nothing beyond their (active or silent) influence (Wettstein 2009, 213-16).

More than 50 years earlier, Bowen describes the extent of influence of economic activity on everyone's life in an ostensibly similar way: "it comprises so large an element of human time, of human interrelationship, and of personality expression. It is not only a means to human life and human ends but a large part of human life, and an end in itself" (Bowen 2013, 11). Yet, Bowen does not equate influence with actual power. This allows him to discuss both the extent and the restrictions of power that enable or disable companies to assume responsibility. He thereby accounts for an intermediary model of business power between extensive and narrow views.

Lastly, narrow accounts of business power emphasise the difficulties and restrictions that companies face when it comes to influencing issues beyond their immediate reach (or even within). Such difficulties may be due to competition and economic pressure, political and legal restrictions, protectionism, the mere extent and complexity of global markets and global production and the fractions in global supply and value chains. ${ }^{13}$

The latter examples show that business power does not simply rise or decline with the size and resources of a company, i.e. its instrumental power. However, narrow accounts of business power tend to emphasise a company's instrumental power, while broad accounts explicitly address the discursive and productive forms of power as well. In the following, our concept of business power draws upon that tendency, operationalizing narrow business power as restricted agency and influence, mostly in terms of instrumental power, and broad business power containing instrumental, productive as well as discursive power.

\footnotetext{
$\overline{12}$ The socializing and norm-setting power of networks between slave-holding companies illustrates this point (Chesney et al. 2019).

${ }^{13}$ Cf. Crane, Matten, and Moon 2008, 46 who otherwise argue that even with a narrow account of business power, companies can exercise influence over a number of issues, including political ones (Crane et al. 2008a, 2008b, 77ff.).
} 


\section{Internal and External Realms of Business Agency}

The second aspect of business responsibility captures the differentiation between internal and external realms of business activities. It relates to, but transcends the differentiation between immediate business interests on the one hand, and broader defined social, public or human rights interests on the other hand.

The internal realm includes the governance of processes and structures concerned with planning, decision making and control of business affairs (Becker and Ulrich 2010 , 8). It primarily affects employees (Crouch 2010, 35), employers and shareholders - i.e. those groups and individuals that are internal to a company.

The external realm covers business relations with external actors, conditions and structures (Hardtke 2010, 15; Becker and Ulrich 2010, 8). These include not only market demands and legal regulations, but also environmental issues and societal norms. It captures how business becomes increasingly involved with political, external and public concerns (Crane et al. 2008a, b; Moon 2002). The external relation works in both directions. On the one hand, it contains the effects of business activities on the external realm (the environment, society, regulation, law-making, norms etc.). On the other, it contains the external realm's (legal, institutional, moral) effects, conditions, restrictions and expectations that a company is supposed to meet, including societal norms and values (Joyner and Payne 2002, 300; Bowen 2013). In the external realm, companies face a high diversity of stakeholders, encompassing all groups and individuals (or their representatives) that may be directly or indirectly affected by a company's activities (Freeman 2010, 46; de George 2011, 189).

Both sides interact. Their interaction and intermediation becomes visible in the, sometimes indistinct, lines between external and internal realms of business conduct, and in the ways that agency in one realm is influenced by conditions in the other realm.

The internal and external realms of business agency are a relevant aspect of business responsibility, because they mirror the questions of business interests and purpose, and the ways that a company's concrete behaviour is embedded in enabling or restricting structures.

\section{Public and Private Business Roles}

The third aspect of business responsibility is dedicated to the role of business actors with regard to the "great dichotomy" between public and private (Bobbio 1997). The on-going debate in both CSR and BHR scholarship is marked by the controversial question, whether business actors should be seen as mere private, economic actors pursuing private interests, or whether they rather resemble public, political actors with public responsibilities (Scherer and Palazzo 2008, 419-20; Levy and Kaplan 2008, 434; Kobrin 2009; Muchlinski 2001). These two positions build the poles on the spectrum between public and private roles of business actors.

A middle ground between the poles argues that the relation between public and private cannot be described as a binary dichotomy in the first place. Instead, they interrelate in a mutually constitutive relation (Mende 2020a, b). In the middle of the spectrum, then, the role of business actors eases out of the distinction between public and private. Business activities affect public affairs and public goods (e.g. 
infrastructure, health, education and private security and military services). In certain regards, companies can be said to act like a government (Crane et al. 2008a, b, 50-54).

However, business actors do not simply equal public actors. They are not democratically legitimated, and public goods are not their genuine purpose (Abrahamsen and Williams 2014). Furthermore, there are functions and structures inherent to governments for which there are no equivalents in companies (Crane et al. 2008a, b, 67).

Business actors thus increasingly develop a hybrid role that is situated between, and simultaneously beyond, the public and the private (Mende 2020a). On the umbrella spectrum, the public business roles strongly resonate with the productive and discursive forms of business power, and with the external realm of business activities.

\section{Business Responsibility: a Pathway}

We propose a model of business responsibility that is based on the aspects of business power, internal and external realms, and public and private business roles, as they are being discussed both in CSR and BHR. These three interrelated aspects contribute to an umbrella spectrum of business responsibility between a narrow and a broad model (cf. Table 2). The ideal-typical narrowest model of business responsibility assumes companies to be merely private actors (one pole in spectrum 3), responsible only for the internal realm of their activities (one pole in spectrum 2) and only capable of assuming a narrow range of responsibility due to their narrow range of power, mainly related to instrumental power (one pole in spectrum 1).

The ideal-typical broadest model of business responsibility, on the other hand, assumes companies or their interests to be (equivalent to) public ones (the other pole in spectrum 3), responsible for extensive external realms of their activities (the other pole in spectrum 2) and capable of acting upon that responsibility, due to a broad scope of their power, including productive and discursive power (the other pole in spectrum $1)$.

The umbrella spectrum of business responsibility between a narrow and a broad model builds the basis for our pattern of business responsibility for modern slavery.

Table 2 Two models of business responsibility

\begin{tabular}{llll}
\hline Umbrella spectrum & Narrow business responsibility & [Spectrum] & Broad business responsibility \\
\hline Spectrum 1 & $\begin{array}{c}\text { Narrow business power } \\
\text { (restricted, instrumental) }\end{array}$ & $\rightarrow$ & $\begin{array}{c}\text { Broad business power } \\
\text { (extensive, instrumental, } \\
\text { productive, discursive) }\end{array}$ \\
Spectrum 2 & $\begin{array}{c}\text { Internal realm (directly affected } \\
\text { shareholders, business } \\
\text { and economic affairs) }\end{array}$ & $\rightarrow$ & $\begin{array}{c}\text { External realm (directly } \\
\text { and indirectly affected } \\
\text { stakeholders, social and } \\
\text { political affairs) }\end{array}$ \\
Spectrum 3 & Private business roles & $\rightarrow$ & \begin{tabular}{c} 
Public business roles \\
\hline
\end{tabular}
\end{tabular}




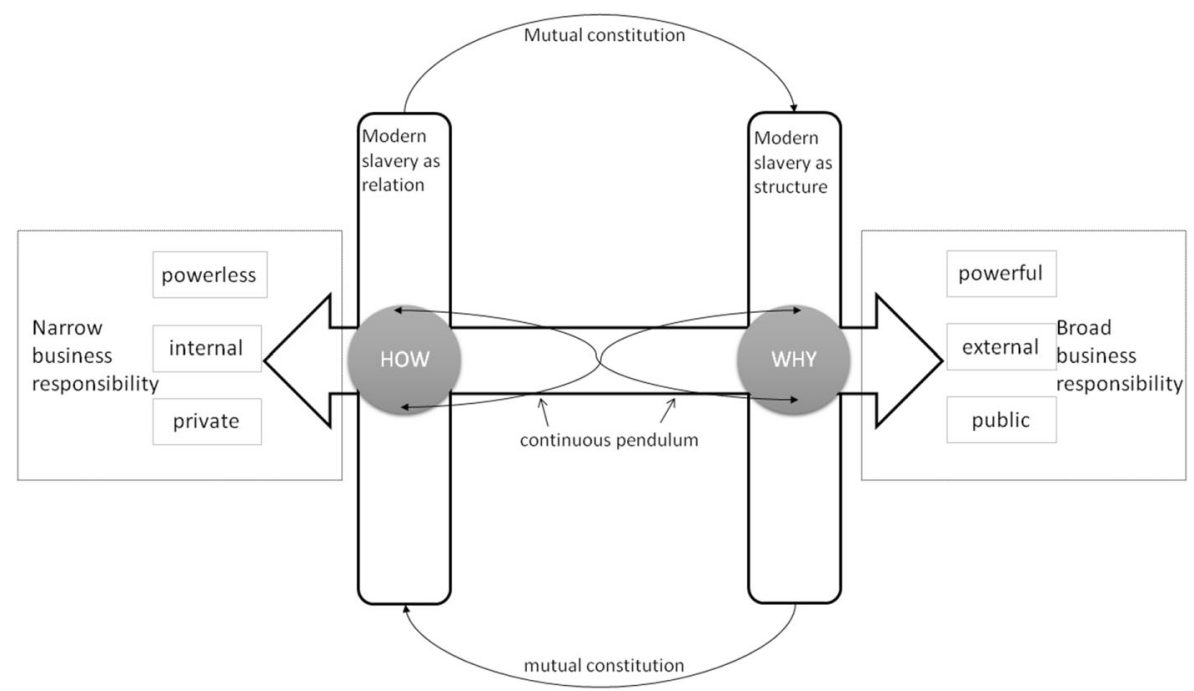

Fig. 1 Two junctions between modern slavery and business responsibility. The two mutually constitutive models of modern slavery (vertical boxes) intersect with the two models of business responsibility (horizontal spectrum) at two junctions (grey circles). Each junction indicates the forms (how) and the reasons (why) for business responsibility for modern slavery

\section{The Junction: Business Responsibility for Modern Slavery}

The previous sections provide a pathway to modern slavery, on the one hand, and business responsibility, on the other. The present section crosses these pathways in two junctions, to stay in the picture. It connects the two models of slavery with the two models of business responsibility. The result is a pattern (cf. Fig. 1) which allows making use of the strength of each junction, as well as identifying its limits.

\section{Narrow Business Responsibility for Modern Slavery as Relation}

Modern slavery as relation concerns business responsibility with regard to the relation between an employer and a worker. It connects the aspect of control to an employer, a company, a contractor or, more generally, to someone who skims the profit of the worker's labour. The narrow model of business responsibility allows tackling modern slavery as relation. Since the latter emphasises intentional actions as causes of modern slavery, this junction provides a clear delineation and demarcation of business responsibility, thereby providing a strong foundation for its translation into legal terms, governance mechanisms and concrete, agency-oriented mechanisms. It thus addresses how companies can resume responsibility.

The narrow model strongly resonates with a range of practices in corporate governance. ${ }^{14}$ This includes strategies focussing on supplier development, such as strategic partnership models and corrective action plans (Allain 2013, 60), technology and knowledge transfer, financial assistance, and supplier education (Yawar and Seuring

\footnotetext{
${ }^{14}$ Also cf. New 2020, suggesting that the view of modern slavery as criminal aberration corresponds with classic CSR policies in corporate governance.
} 
2017, 626). It also includes the adoption and implementation of codes of conduct and standards (Ciliberti et al. 2009; Schrempf-Stirling and Palazzo 2016, 502), the establishment of management systems for social issues, CSR trainings for employees (Preuss 2009, 742), auditing measures (Allain 2013, 57; Stevenson and Cole 2018, 86) and incentivizing and rewarding suppliers for compliance (Stiller and Gold 2014, 56-59). A third area of corporate governance is dedicated to risk-avoidance, e.g. the avoidance of non-permanent migrant and seasonal labour, and strict gate-keeping for new suppliers (Stevenson and Cole 2018, 90).

Our point is the following: Slavery as relation between an employer and a worker can even be tackled by a company that is acting purely private, in its own interest and its internal realm, with restricted power, and that is just supposed to follow hard law. This close congruence between slavery as relation and narrow business responsibility provides a basis for the question of how to tackle modern slavery.

\section{Broad Business Responsibility for Modern Slavery as Structure}

Modern slavery as a structural problem means focussing on the conditions that enable slavery. This speaks to a broad model of business responsibility. If slavery is enabled by structural economic pressure and embedded in cultural and societal settings, it not only transcends the relation between worker and employer, but also the narrow responsibility of a company. The junction between slavery as structure with a broad business responsibility provides perspectives as to why a company should get involved in tackling slavery.

The question of why a company should be responsible for modern slavery beyond its internal private reach touches several aspects. First, as shown above, slavery as a relation is enabled by structural conditions. This means that the approach to slavery as structure does not dismiss the approach to slavery as relation. The two are not mutually exclusive, but the latter is embedded in the former. For slavery as relation to work, it relies on enabling structures and conditions.

Second, the broad model of business responsibility emphasises the two-fold connection between the internal and the external realms of business conduct. This means that companies internally exploiting slavery as a relation may not only directly profit from external structures and conditions that enable slavery, but they also may contribute to them strategically (beyond mere reproduction of the social process of modern slavery). Companies that seek to profit from very cheap labour may actively search for areas that provide slavery-enabling conditions. In the global competition for foreign direct investments, such conditions may not only remain untouched, but they may even be exacerbated in order to attract investments and companies (Wettstein 2009, 235; New 2015, 703). Business is increasingly assuming an extensive role in gaining from, contributing to, being involved in, and yielding productive and discursive power over external, societal and political issues, including those concerning structures that enable slavery (Crane et al. 2008a, b, 30). Accordingly, Haake and Seuring (2009) suggest to also consider non-product-related procurement in risk-based approaches.

To a certain degree, the broad model of business responsibility resonates with management strategies that are dedicated to indirect measures. These include coalitions and working groups with other companies in the industry or joint corporate initiatives (Crane 2013, 65; Schrempf-Stirling and Palazzo 2016, 502; Stevenson and Cole 2018, 
90), and community-centred approaches to address social structures. These strategies may intersect with company engagement in multi-stakeholder initiatives, the cooperation with local governments, NGOs and trade unions (Gold et al. 2015, 489-90; Schrempf-Stirling and Palazzo 2016, 502-4). Transparency and information disclosure about supply chains and suppliers, or sustainability reporting are also able to address slavery as structure (Gold et al. 2015; Stevenson and Cole 2018, 89; Yawar and Seuring 2017, 626), if they are accompanied by strong institutional mechanisms (New 2020) that include pivotal actors such as states and local communities (Kelling et al. 2020).

Hence, the junction goes beyond management or CSR strategies. First, it emphasises the reasons why companies should be concerned with slavery as structure. Second, it emphasises that management strategies need to be embedded with broader processes and mechanisms. As New (2020) puts it: "The challenge of modern slavery is political. It will not be solved by modest additions to corporate reporting, nor by ethical shopping by occasionally attentive consumers." This is because companies exercise both public and private (political and economic) roles, as captured by the hybrid model introduced above.

In sum, the junction between broad business responsibility and slavery as structure allows taking into account the dimensions and structures enabling slavery, the ways they intersect with business power, effects, and roles, and the indirect effects of business behaviour. Therefore, the broad model addresses the question of why business companies should resume responsibility for slavery as structure.

\section{Strengths and Limits}

The previous section develops a pattern of business responsibility for modern slavery by crossing broad business responsibility with slavery as structure, and narrow business responsibility with slavery as relation. This section scrutinises the two junctions by discussing the strengths and limits of each. It shows that, ultimately, only both junctions taken together build the foundation for tackling slavery. This is because each junction's limits can be addressed by drawing on the other, respectively. Therefore, we do not suggest to simply dissolve the different approaches. Rather, discussions of business responsibilities for modern slavery need to oscillate between the two junctions in a continuous pendulum.

The first junction, narrow business responsibility for slavery as relation, provides a viable and feasible foundation for the question of how to tackle modern slavery. It benefits from targeted strategies and a dedication to details in business relations. Yet, this model relies on external conditions. Here, the mutual constitution of structure and agency comes into play. The narrow model is dependent, e.g. on the capacity and willingness of states to enforce hard law prohibiting slavery, and the capacity and willingness of companies to adhere to the law. These conditions may be lacking, especially when it comes to areas of limited statehood, global supply chains or certain local conditions.

For example, the competition for foreign direct investments might impede upon the successful eradication of slave labour. The lax implementation of legal provisions might become part of a state's political economy. Investment schemes in which prices 
are the major motivation to invest are more likely to build upon labour relations that are less regulated (Mosley 2011). Alongside state strategies to attract foreign direct investments, local competitors might perceive slavery as a rational business strategy under conditions of price competition and refuse to follow the law. ${ }^{15}$ Furthermore, corruption can constitute structural conditions in which slavery can thrive, either on the side of state officials in preventing inspections, or on the side of labour inspectors and the police (Lusk and Lucas 2009). Problems at lower tiers of supply chains result from structural issues that are passed down its tiers (New 2020). Global supply chains thus induce fragmented production networks in which slavery exists beyond a company's direct control (Lund-Thomsen and Lindgreen 2014, 11-22). ${ }^{16}$ At the same time, "the spatial disbursement of productive processes" (Taylor 2008b, 18) into single, geographically separate units is a common corporate strategy to maximise profits (Helpman 2011, 127; Göbel 2010, 14), to reduce risk and to enhance flexibility (Standing 2000). An ever increasing and complex "cascade system" (Barrientos 2011,4 ) with a multiplicity of tiers emerges. ${ }^{17}$ Additionally, business is more likely to succeed in establishing or benefitting from slavery relations, if the latter are reinforced by socially accepted norms and structures, repressive migration politics, or deprived living conditions.

In all of these dimensions, the possibility of internally and privately profiting from slavery is closely linked to external and public conditions. This is where the broad business responsibility for slavery as structure comes in.

The second junction, broad responsibility for slavery as structure, takes the conditions and structures into account that lie beyond a company's internal agency, but that actively contribute to the existence and possibility of modern slavery. The broad responsibility for slavery as structure addresses the question of why companies should care about external conditions that enable modern slavery. It thus focusses on the rationale for broad business responsibility. At the same time, it is limited and corrected by the narrow model. In line with management studies and risk-based approaches, we acknowledge that companies cannot control and monitor all parts of their business relations (also cf. Haake and Seuring 2009). Hence, they cannot assume responsibility for every dimension of slavery as structure.

This is because these external conditions do not just exist in their relation to business conduct. Societal and cultural structures of racism, sexism or caste systems can exist prior to and independent of business conduct. The United States Victims of Trafficking and Violence Protection Act emphasises "poverty [...] and the lack of economic opportunities" (United States of America 2000, Section 102.b.4) as one of the major reasons for modern slavery (also cf. Crane 2013). These economic factors cannot always be connected to directly and intentionally responsible actors, let alone to a certain company. Accordingly, the ILO states that "the employer or the State are not accountable for all external constraints or indirect coercion existing in practice; for

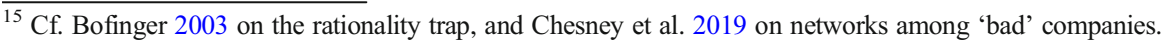

${ }^{16}$ There is a lively debate about whether, and if so, how global supply chains influence labour standards (Distelhorst et al. 2015). It is argued that their effects on labour standards depend on the financial strategy of the lead firm. While foreign direct investments (horizontal investments) raise labour standards, subcontracting schemes (vertical investments) depress them (Mosley 2011).

${ }^{17}$ This also applies to the supply of labour (van der Linden 2008) and to domestic supply chains (Crane et al. 2017).
} 
example, the need to work in order to earn one's living could become relevant only in conjunction with other factors for which they are answerable" (ILO 2003, 37).

This poses the question of the limits of broad business responsibility, and whether slavery as structure is relevant for business responsibility at all. This question resembles BHR discussions about adverse human rights impact that companies benefit from, but do not directly contribute to. The UN Framework on Business and Human Rights, the intermediary report for the United Nations Guiding Principles on Business and Human Rights (United Nations 2011), addresses this point:

To begin with, sphere of influence conflates two very different meanings of influence: one is impact, where the company's activities or relationships are causing human rights harm; the other is whatever leverage a company may have over actors that are causing harm. The first falls squarely within the responsibility to respect; the second may only do so in particular circumstances. [...] Anchoring corporate responsibility in the second meaning of influence requires assuming, in moral philosophy terms, that 'can implies ought'. But companies cannot be held responsible for the human rights impacts of every entity over which they may have some influence, because this would include cases in which they were not a causal agent, direct or indirect, of the harm in question (HRC 2008, §§ 68-69).

At the same time, there is a lively discussion that a company's power should be one of the factors giving rise to its responsibility (Wood 2012; Wettstein 2012). Our model contributes to that discussion by specifying power as instrumental, productive and discursive power also in the public sphere. We argue that companies benefit from structural conditions to which they may or may not contribute to, and that their behaviour has effects on those conditions - due to the mutual constitution of agency and structure. This does not mean to equate power with responsibility, but it explains why companies should be concerned with slavery as structure. To be sure, one challenge remains: where to draw the line?

At this point, the narrow business responsibility for slavery as relation comes into play again. It provides for precision. First, slavery as relation can be identified via concrete items and phenomena; second, narrow business responsibility builds the basis for developing concrete mechanisms, demands and benchmarks. This junction therefore allows for feasible political, legal and managerial strategies. It can be further strengthened by the approach introduced above as a middle ground in the spectrum of business responsibility, ascribing both private and public roles to companies (Mende 2020a).

At the same time, the model of broad business responsibility for slavery as structure serves as an ineluctable reminder that modern slavery as relation cannot be detached from its enabling structures and conditions - and neither can narrow business responsibility. This is because companies may benefit from and contribute to structural conditions, as well as to the agency of other actors such as states, e.g. by "supporting oppressive regimes and discouraging legal and social improvements that could empower or protect vulnerable people." (New 2020) This ability is closely connected to the productive and discursive power of companies, hence to the dimensions of broad responsibility. Again, the mutual constitution between structure and agency applies. Structures are reproduced by actors-including companies. For this reason, we suggest 
the model of broad business responsibility for slavery as structure to be useful for correcting and extending the narrow model — and vice versa.

Ultimately, the discussion of business responsibility is in need of a continuous pendulum between the two junctions (cf. Fig. 1). Only if both models are included, each junction's strength can be employed, while each junction's limits can be corrected by its counterpart in a continuous pendulum.

Tackling modern slavery thus benefits from considering both junctions. The pattern of a pendulum enables both targeted policies and the consideration of broader context. Our pattern allows companies to navigate and prioritise their engagement in tackling modern slavery, not only by underlining the importance of targeted strategies, but also by rendering those issues visible that lie beyond questions of mere corporate governance. Additionally, it contributes to the discussion (especially when it comes to supply chains), why companies should assume responsibilities beyond their immediate reach. Ultimately, our pattern includes both corporate governance strategies as well as political, legal, normative and social measures that include, but are not limited to, business behaviour. Tackling modern slavery needs to address causes for slavery, in which a variety of actors, relations and structures are involved. Our pattern reveals these causes, and demonstrates that companies are not dichotomously dissociated from them.

\section{Conclusion}

This paper aims at developing a pattern of business responsibility for modern slavery. To that end, it delineates the complex concepts of modern slavery and business responsibility, respectively. We define modern slavery with the interconnected models of slavery as relation and slavery as structure; and we define business responsibility along a spectrum between broad and narrow forms, qualified by power, internal and external effects, private and public roles. By developing clear models, this article provides a pathway to each field. In a next step, the article crosses these pathways at two junctions. It shows how narrow business responsibility intersects with modern slavery as relation, and how broad business responsibility intersects with modern slavery as structure. These two junctions allow discussing how and why business companies should resume responsibility for modern slavery. With a continuous pendulum between the two junctions, each junction's strength can be preserved, while its limits can be redressed.

Business-related forms of slavery as relation can be addressed by a narrow concept of business responsibility. However, they are embedded in structural contexts which enable modern slavery in the first place. The broad model of business responsibility for slavery as structure addresses the latter. Yet, it entails the danger of becoming too broad and thus too vague. This is where narrow business responsibility for modern slavery as relation provides for concrete definitions and measures.

Taken together, both junctions provide ways of addressing slavery. Both junctions are intertwined - without merging into one diffuse model. They supplement each other by addressing the question of how and why companies should assume responsibility for modern slavery, providing an analytical, a practical and a normative foundation for tackling modern slavery. 
Funding Information Open Access funding provided by Projekt DEAL. This paper is based on research that is funded by the Deutsche Forschungsgemeinschaft (DFG, German Research Foundation), project number 398306144 .

Open Access This article is licensed under a Creative Commons Attribution 4.0 International License, which permits use, sharing, adaptation, distribution and reproduction in any medium or format, as long as you give appropriate credit to the original author(s) and the source, provide a link to the Creative Commons licence, and indicate if changes were made. The images or other third party material in this article are included in the article's Creative Commons licence, unless indicated otherwise in a credit line to the material. If material is not included in the article's Creative Commons licence and your intended use is not permitted by statutory regulation or exceeds the permitted use, you will need to obtain permission directly from the copyright holder. To view a copy of this licence, visit http://creativecommons.org/licenses/by/4.0/.

\section{References}

Abrahamsen R and Williams MC (2014) Publics, practices and power. In: Best J and Gheciu A (eds) The return of the public in global governance: Cambridge: Cambridge University Press, pp. 243-256.

Ad Hoc Committee on Slavery (1951) Report of the Ad Hoc Committee on Slavery: E/1988.

Addo MK (ed) (1999) Human rights standards and the responsibility of transnational corporations. The Hague: Kluwer.

Akurang-Parry KO (2010) Transformations in the feminization of unfree domestic labor: a study of Abaawa or prepubescent female servitude in modern Ghana. International Labor and Working-Class History 78(1): $28-47$.

Allain J (2013) Slavery in international law: of human exploitation and trafficking. Boston, Mass.: Martinus Nijhoff Publishers.

Allain J and Hickey R (2012) Property and the definition of slavery. International and Comparative Law Quarterly 61(04): 915-938.

Bales K (2005) New slavery: a reference handbook. Santa Barbara: ABC-CLIO.

Bales K (2016) Blood and earth: modern slavery, ecocide, and the secret to saving the world. New York: Spiegel \& Grau.

Barrientos S (2011) 'Labour chains': Analysing the role of labour contractors in global production networks. Manchester: Brooks World Poverty Institute.

Barrientos S, Kothari U and Phillips N (2013) Dynamics of unfree labour in the contemporary global economy. Journal of Development Studies 49(8): 1037-1041.

Becker W and Ulrich P (2010) Corporate governance and controlling: Begriffe und Wechselwirkungen. In: Keuper F and Neumann F (eds) Corporate governance, risk management und compliance: innovative Konzepte und Strategien. Wiesbaden: Gabler, pp. 5-28.

Bobbio N (1997) The great dichotomy: public/private. In: Democracy and dictatorship: The nature and limits of state power. Oxford: Polity Press, pp. 1-21.

Bofinger P (2003) Grundzüge der Volkswirtschaftslehre: Eine Einführung in die Wissenschaft von Märkten. München: Pearson Studium.

Bowen HR (2013) Social responsibilities of the businessman: introduction by Jean-Pascal Gond. Foreword by Peter Geoffrey Bowen. University of Iowa Press.

Brysk A (2012) Rethinking trafficking: human rights and private wrongs. In: Brysk A and Choi-Fitzpatrick A (eds) From human trafficking to human rights: reframing contemporary slavery. Philadelphia: University of Pennsylvania Press, pp. 73-85.

Campbell T (2012) Corporate social responsibility: beyond the business case to human rights. In: Cragg W (ed.) Business and human rights: Cheltenham: Edward Elgar Pub, pp. 47-73.

Carroll AB (2008) A history of corporate social responsibility: concepts and practices. In: Crane A (ed.) The Oxford handbook of corporate social responsibility: Oxford: Oxford University Press, pp. 19-46.

Chesney T, Evans K, Gold S, et al. (2019) Understanding labour exploitation in the Spanish agricultural sector using an agent based approach. Journal of Cleaner Production 214: 696-704.

Choi-Fitzpatrick A (2012) Rethinking trafficking: contemporary slavery. In: Brysk A and Choi-Fitzpatrick A (eds) From human trafficking to human rights: reframing contemporary slavery. Philadelphia: University of Pennsylvania Press, pp. 13-24. 
Choi-Fitzpatrick A (2017) What slaveholders think: how contemporary perpetrators rationalize what they do. New York, NY: Columbia University Press.

Ciliberti F, de Groot G, de Haan J, et al. (2009) Codes to coordinate supply chains: SMEs' experiences with SA8000. Supply Chain Management: An International Journal 14(2): 117-127 (accessed 23 July 2018).

Cragg W (2012) Ethics, enlightened self-interest, and the corporate responsibility to respect human rights. Business Ethics Quarterly 22(1): 9-36.

Craig G, Gaus A, Wilkinson M, et al. (2007) Contemporary slavery in the UK: overview and key issues. York: Joseph Rowntree Foundation.

Crane A (2013) Modern slavery as a management practice: exploring the conditions and capabilities for human exploitation. Academy of Management Review 38(1): 49-69.

Crane A, Matten D and Moon J (2008a) Corporations and citizenship. Cambridge: Cambridge University Press.

Crane A, McWilliams A, Matten D, et al. (2008b) The corporate social responsibility agenda. In: Crane A (ed.) The Oxford handbook of corporate social responsibility: Oxford: Oxford University Press, pp. 4-15.

Crane A, Lebaron G, Allain J, et al. (2017) Governance gaps in eradicating forced labor: from global to domestic supply chains Regulation \& Governance 35(online first).

Crouch C (2010) CSR and changing mode of governance: towards corporate noblesse oblige? In: Utting P and Marques JC (eds) Corporate social responsibility and regulatory governance: Towards inclusive development? Houndmills, Basingstoke, Hampshire: Palgrave Macmillan.

Cutler AC, Haufler V and Porter T (1999) Private authority and international affairs. In: Cutler AC, Haufler V and Porter T (eds) Private authority and international affairs: Albany: State University of New York Press, pp. 3-27.

de Bakker F, Groenewegen P and Den Hond F (2005) A bibliometric analysis of 30 years of research and theory on corporate social responsibility and corporate social performance. Business \& Society 44(3): 283-317.

de George RT (2011) Business ethics. New Delhi: Dorling Kindersley, licensees of Pearson Education in South Asia.

Deva S (2013) Treating human rights lightly: a critique of the consensus rhetoric and the language employed by the Guiding Principles. In: Deva S and Bilchitz D (eds) Human rights obligations of business: beyond the corporate responsibility to respect? Cambridge: Cambridge University Press, pp. 78-103.

Distelhorst G, Locke RM, Pal T, et al. (2015) Production goes global, compliance stays local: Private regulation in the global electronics industry. Regulation \& Governance 9(3): 224-242.

Dottridge M (2005) Types of forced labour and slavery-like abuse occurring in Africa today: a preliminary classification. Cahiers d'Études Africaines 45(179/180): 689-712.

Drubel J (2019) Regulation by visibility: new forms of global social governance. Global Social Policy 19(3): 188v206

Epstein EM (1973) Dimensions of corporate power, part 1. California Management Review 16(2): 9-23.

Epstein EM (1974) Dimensions of corporate power, part 2. California Management Review 16(4): 32-47.

Fransen L and Lebaron G (2018) Big audit firms as regulatory intermediaries in transnational labor governance. Regulation \& Governance(online first).

Freeman RE (2010) Strategic management: A stakeholder approach. Cambridge: Cambridge University Press.

Friedman M (2007) The social responsibility of business is to increase its profits: The New York Times Magazine. 13. September 1970. Reprint. In: Zimmerli WC, Holzinger M and Richter K (eds) Corporate ethics and corporate governance: Berlin: Springer.

Fuchs D (2004) The role of business in global governance. In: Schirm SA (ed.) New rules for global markets: public and private governance in the world economy. Houndmills, Basingstoke, Hampshire, New York: Palgrave Macmillan, pp. 133-154.

Fuchs D (2005) Understanding business power in global governance. Baden-Baden: Nomos.

Galtung J (1969) Violence, peace, and peace research. Journal of Peace Research 6(3): 167-191.

Göbel T (2010) Decent work and transnational governance: multi-stakeholder initiatives' impact on labour rights in global supply chains. Baden-Baden: Nomos.

Gold S and Schleper MC (2017) A pathway towards true sustainability: a recognition foundation of sustainable supply chain management. European Management Journal 35(4): 425-429.

Gold S, Trautrims A and Trodd Z (2015) Modern slavery challenges to supply chain management. Supply Chain Management: An International Journal 20(5): 485-494 (accessed 22 July 2018).

Gond J-P and Moon J (eds) (2012) Corporate social responsibility: Volume 1. London: Routledge.

Greene SE (2009) Modern Trokosi and the 1807 abolition in Ghana: connecting past and present. The William and Mary Quarterly 66(4): 959-974. 
Haake H and Seuring S (2009) Sustainable procurement of minor items - exploring limits to sustainability. Sustainable Development 17(5): 284-294.

Hardtke A (2010) Das CSR-Universum. In: Hardtke A and Kleinfeld A (eds) Gesellschaftliche Verantwortung von Unternehmen: Von der Idee der Corporate Social Responsibility zur erfolgreichen Umsetzung. Wiesbaden: Gabler, pp. 13-70.

Harvey D (2006) The limits to capital. London, New York: Verso.

Hathaway JC (2008) The human rights quagmire of "human trafficking". Virginia Journal of International Law 49(1): 1-59.

Haynes K, Murray A and Dillard J (eds) (2013) Corporate social responsibility: a research handbook. Abingdon: Routledge.

Helpman E (2011) Understanding global trade. Cambridge: The Belknap Press of Harvard University Press. Herzfeld B (2002) Slavery and gender: Women's double exploitation. Gender and Development 10(1): 50-55.

HRC (2008) Protect, respect and remedy: a framework for business and human rights: Report of the Special Representative of the Secretary-General on the issue of human rights and transnational corporations and other business enterprises, John Ruggie. A/HRC/8/5. Geneva: Human Rights Council.

ILO (1930) Forced labour: Report I, second discussion. International Labour Conference, 14th Session.

ILO (2003) Fundamental rights at work and international labour standards. Geneva: International Labor Office.

ILO (2012) ILO global estimate of forced labour: results and methodology. Geneva: International Labour Office.

Joyner BE and Payne D (2002) Evolution and implementation: a study of values, business ethics and corporate social responsibility. Journal of Business Ethics 41(4): 297-311.

Kelling NK, Sauer PC, Gold S, et al. (2020) The role of institutional uncertainty for social sustainability of companies and supply chains. Journal of Business Ethics(online first).

Kobrin SJ (2009) Private political authority and public responsibility: transnational politics, transnational firms, and human rights. Business Ethics Quarterly 19(03): 349-374.

Kurucz EC, Colbert BA and Wheeler D (2008) The business case for corporate social responsibility. In: Crane A (ed.) The Oxford handbook of corporate social responsibility: Oxford: Oxford University Press, pp. $83-112$.

Landman T (2018) Hidden in plain sight: A cross-national analysis of modern slavery prevalence. Rights Lab Working Paper, University of Nottingham.

Lawrance BN (2010) From child labor 'problem' to human trafficking 'crisis': child advocacy and antitrafficking legislation in Ghana. International Labor and Working-Class History 78(1): 63-88.

League of Nations (1926) Slavery Convention.

Lebaron G and Ayers AJ (2013) The rise of a 'new slavery'? Understanding African unfree labour through neoliberalism. Third World Quarterly 34(5): 873-892.

Lebaron G and Phillips N (2018) States and the political economy of unfree labour. New Political Economy 24(1): $1-21$.

Lerche J (2007) A global alliance against forced labour?: unfree labour, neo-liberal globalization and the International Labour Organization. Journal of Agrarian Change 7(4): 425-452.

Levy DL and Kaplan R (2008) Corporate social responsibility and theories of global governance: strategic contestation in global issue arenas. In: Crane A (ed.) The Oxford handbook of corporate social responsibility: Oxford: Oxford University Press, pp. 432-451.

Lockett A, Moon J and Visser W (2006) Corporate social responsibility in management research: focus, nature, salience and sources of influence. Journal of Management Studies 43(1): 115-136.

Lukes S (2005) Power: a radical view. Basingstoke: Palgrave Macmillan.

Lund-Thomsen P and Lindgreen A (2014) Corporate social responsibility in global value chains: where are we now and where are we going? Journal of Business Ethics 123(1): 11-22.

Lusk M and Lucas F (2009) The challenge of human trafficking and contemporary slavery. Journal of Comparative Social Welfare 25(1): 49-57.

Massey DB (1995) Spatial divisions of labour: social structures and the geography of production. Basingstoke: Macmillan.

McGrath S (2012) Many chains to break: the multi-dimensional concept of slave labour in Brazil. Antipode 45(4): 1005-1028.

Mende J (2016) A human right to culture and identity? The ambivalence of group rights. London: Rowman \& Littlefield International.

Mende J (2019) The concept of modern slavery: definition, critique, and the human rights frame. Human Rights Review 20(2): 229-248. 
Mende J (2020a) The public, the private, and the business-societal: a threefold approach to business responsibility for human rights. In: Brysk A and Stohl M (eds) Research agendas for human rights: Cheltenham: Edward Elgar Publishing, forthcoming.

Mende J (2020b) Business authority in global governance: beyond public and private. WZB Berlin Social Science Center Discussion Paper SP IV 2020-103.

Mezzadra S and Neilson B (2013) Border as method, or, the multiplication of labor.

Miers S (2000) Contemporary forms of slavery. Canadian Journal of African Studies 34(3): 714-747.

Miers S (2003) Slavery: a question of definition. Slavery \& Abolition 24(2): 1-16.

Moon J (2002) The social responsibility of business and new governance. Government and Opposition 37(03): 385-408.

Moravcsik J (1998) Slavery and the ties that do not bind. In: Lott TL (ed.) Subjugation and bondage: critical essays on slavery and social philosophy. Lanham: Rowman \& Littlefield, pp. 171-186.

Mosley L (2011) Labor rights and multinational production. Cambridge, New York: Cambridge University Press.

Muchlinski P (2001) Human rights and multinationals: is there a problem? International Affairs 77(1): 31-48.

New SJ (2015) Modern slavery and the supply chain: the limits of corporate social responsibility? Supply Chain Management: An International Journal 20(6): 697-707 (accessed 22 Jul 2018).

New S (2020) Modern slavery and supply chain transparency. In: Choi T-M (ed.) The Oxford handbook of supply chain management: Oxford: Oxford University Press, forthcoming.

O’Connell Davidson J (2015) Modern slavery: the margins of freedom. Basingstoke u.a.: Palgrave Macmillan.

Ollus N (2015) Regulating forced labour and combating human trafficking: the relevance of historical definitions in a contemporary perspective. Crime, Law and Social Change 63(5): 221-246.

Peterson VS (2003) A critical rewriting of global political economy: integrating reproductive, productive, and virtual economies. London, New York: Routledge.

Preuss L (2009) Ethical sourcing codes of large UK-based corporations: prevalence, content, limitations. Journal of Business Ethics 88(4): 735-747 (accessed 22 Jul 2018).

Quirk J (2012) Uncomfortable silences: contemporary slavery and the 'lessons' of history. In: Brysk A and Choi-Fitzpatrick A (eds) From human trafficking to human rights: reframing contemporary slavery. Philadelphia: University of Pennsylvania Press, pp. 25-43.

Ramasastry A (2015) Corporate social responsibility versus business and human rights: bridging the gap between responsibility and accountability. Journal of Human Rights 14(2): 237-259.

Rasche A (2015) The corporation as a political actor: European and North American perspectives. European Management Journal 33(1): 4-8.

Research Network on the Legal Parameters of Slavery (2012) Bellagio-Harvard Guidelines on the Legal Parameters of Slavery. Available at: http://www.law.qub.ac.uk/schools/SchoolofLaw/FileStore/Filetoupload,651854,en.pdf (accessed 2 Apr 2017).

Scherer AG and Palazzo G (2008) Globalization and corporate social responsibility. In: Crane A (ed.) The Oxford handbook of corporate social responsibility: Oxford: Oxford University Press, pp. 413-431.

Scherer AG and Palazzo G (2011) The new political role of business in a globalized world: a review of a new perspective on CSR and its implications for the firm, governance, and democracy. Journal of Management Studies 48(4): 899-931.

Scholte JA (2005) Globalization: a critical introduction. New York: Palgrave Macmillan.

Schrempf-Stirling J and Palazzo G (2016) Upstream corporate social responsibility: the evolution from contract responsibility to full producer responsibility. Business \& Society 55(4): 491-527 (accessed 22 Jul 2018).

Schwarz K and Allain J (2020) Antislavery in domestic legislation: an empirical analysis of national prohibition globally.

Standing G (2000) Global labour flexibility: seeking distributive justice. Basingstoke [u.a.]: Macmillan [u.a.].

Stevenson M and Cole R (2018) Modern slavery in supply chains: a secondary data analysis of detection, remediation and disclosure. Supply Chain Management: An International Journal 23(2): 81-99 (accessed 22 Jul 2018).

Stiller S and Gold S (2014) Socially sustainable supply chain management practices in the Indian seed sector: a case study. Supply Chain Forum: An International Journal 15(1): 52-67 (accessed 23 Jul 2018).

Storper M and Walker R (1989) The capitalist imperative: territory, technology, and industrial growth. Oxford, UK, New York: B. Blackwell.

Sylwester JG (2014) Fishers of men: the neglected effects on environmental depletion on labor trafficking in the Thai fishing industry. Pacific Rim Law \& Policy Journal 23(2).

Taylor M (ed) (2008a) Global economy contested: power and conflict across the international division of labor. London, New York: Routledge. 
Taylor M (2008b) Power, conflict and the production of the global economy: oo. In: Taylor M (ed.) Global economy contested: power and conflict across the international division of labor. London, New York: Routledge, pp. 11-31.

Taylor N (2014) Theorising capitalist diversity: the uneven and combined development of labour forms. Capital \& Class 38(1): 129-141.

United Nations (1956) Supplementary Convention on the Abolition of Slavery, the Slave Trade, and Institutions and Practices Similar to Slavery. New York: United Nations.

United Nations (1969) Vienna Convention on the law of the treaties. Vienna: United Nations.

United Nations (2000) United Nations Convention Against Transnational Organized Crime and the Protocols thereto.

United Nations (2011) Guiding Principles on Business and Human Rights: Implementing the United Nations "Protect, Respect and Remedy" Framework. New York, Geneva: United Nations.

United Nations Secretary General (1953) Slavery, The Slave Trade, And Other Forms Of Servitude. Report to the UN Economic and Social Council. E/2357. New York: United Nations.

United States of America (2000) Victims of Trafficking and Violence Protection Act. Washington, D.C.

van der Linden M (2008) The 'globalization' of labour and working-class history and its consequences. In: Lucassen J (ed.) Global labour history: A state of the art. Bern, Switzerland, New York: Peter Lang, pp. 13-38.

Wettstein F (2009) Multinational corporations and global justice: the human rights obligations of a quasigovernmental institution. Stanford: Stanford Business Books.

Wettstein F (2012) Silence as complicity: elements of a corporate duty to speak out against the violation of human rights. Business Ethics Quarterly 22(1): 37-61.

Wood S (2012) The case for leverage-based corporate human rights responsibility. Business Ethics Quarterly 22(1): 63-98.

Yawar SA and Seuring S (2017) Management of social issues in supply chains: a literature review exploring social issues, actions and performance outcomes. Journal of Business Ethics 141(3): 621-643 (accessed 22 Jul 2018).

Young IM (2006) Responsibility and global justice: a social connection model. Social Philosophy and Policy 23(1): 102-130.

Publisher's Note Springer Nature remains neutral with regard to jurisdictional claims in published maps and institutional affiliations. 